\title{
PSYCHOLOGICAL CHARACTERISTICS OF MORAL SELF-CONSCIOUSNESS IN CHILDHOOD AND ADOLESCENCE
}

\author{
Liudmyla Kotlova \\ PhD in Psychology, Associate Professor, Associate Professor of \\ the Department of Developmental Psychology and Counseling \\ Ivan Franko Zhytomyr State University \\ 40, Velyka Berdychivska Str., Zhytomyr, Ukraine, 10008 \\ kotlova.lo@i.ua, https://orcid.org/0000-0003-2994-6724
}

\begin{abstract}
The paper presents a theoretical analysis of psychological characteristics of moral selfconsciousness during preschool, primary school and adolescence years. It interprets moral selfconsciousness as a specific form of moral consciousness, awareness of oneself, one's moral values, attitudes, qualities, potentials, actions, their motives and consequences, regulation of one's behaviour and moral self-development. The paper aims to theoretically identify psychological characteristics and mechanisms for developing moral self-consciousness during preschool, primary school and adolescence years. The main objectives are a psychological analysis and the generalization of characteristics of developing moral self-consciousness in childhood and adolescence. Research methods include analysis, synthesis and generalization of scientific works which disclose psychological characteristics of developing moral selfconsciousness, as well as identify the mechanisms for developing them in childhood and adolescence. The paper theorizes that self-esteem in preschool becomes one of the leading motives which stimulates child activity. At the same time, the real and the ideal self, as well as a sound grasp of highly values qualities in society, are not yet clearly differentiated in his or her moral self-consciousness. It leads to a major contradiction in the development of the child's moral self-consciousness, namely, between his or her idealization of himself or herself and experiences associated with how he or she is perceived by others. Self-consciousness starts to develop dramatically at primary school age. The main factors in the development of moral consciousness and self-consciousness of primary school pupils are the sensitivity of their psyche to moral education, an uncompromising attitude to moral requirements for others and the perception of the teacher as a reference person. Self-consciousness is the main newly formed structure of adolescence, namely, when the reflection is developed rapidly, the self-image is formed, the motives of one's activity are realized, and the inner life is becoming rather intimate. Thus, the period of transition from childhood to adolescence is important and contributes to the development of one's moral identity. It is during adolescence that "the solid foundation" of the adult's moral behaviour is laid, and this must be taken into account during the educational process.
\end{abstract}

Keywords: moral self-consciousness, moral behaviour, feelings, reflection, consciousness, selfconsciousness. 


\section{Introduction}

Crisis events in modern society have led to the corruption of moral and social values and, subsequently, to such destructive processes as an increase in the level of corruption, fraud, irresponsibility, asocial acts, bullying, violence. The changes in social structures coincide with changes in morals. The lack of socially approved norms and values destabilizes society and raises certain problems in the context of socialization of younger generations. Currently, Ukrainian society experiences a deep moral crisis. Indeed, people are not aware of spiritual foundations of life, lose the meaning of life and focus on material success and external achievements. The realities of today are market relations and instrumental values.

One of the factors in the development of such processes is a low level of moral selfconsciousness, which is the inner core of personality regulating all aspects of life. It is undeniable that personal morality is correlated with a low level of moral and ethical knowledge, underdeveloped moral skills and feelings, as well as no unity between moral consciousness and behaviour (Овчарова, 2015). Regarding issues concerning young people, moral motivation is distorted; legal and moral nihilism, as well as feelings of permissiveness and impunity, are promoted (Bandura, 2018; Krettenauer, 2020; Walker, 2019). According to some American researchers (Ramos, 2019; Althof, \& Berkowitz, 2006), psycho-pedagogical support for developing a child's moral self-consciousness can help to solve these issues in the future.

In the psycho-pedagogical scientific paradigm, there is no clear opinion on the correlation between consciousness and self-consciousness, what is primary and secondary. V. Bekhterev believed that primary self-consciousness arises before consciousness as a vague, incomprehensible sense of one's existence from the first weeks of life (Бехтерев, 1994). L. Vygotsky and S. Rubinstein insisted on the secondariness of self-consciousness, which arises at a certain stage of consciousness development when language and arbitrary actions are developed, independence is formed, interrelationships are becoming complicated, that is at the age of 2-3 (Выготский, 2005; Рубинштейн, 2006).

The paper agrees with I. Shkilna, who believes that moral self-consciousness as a specific form of moral consciousness, awareness of oneself, one's moral values, attitudes, qualities, potentials, actions, their motives and consequences, regulation of one's behaviour and moral self-development (Шкільна, 2014). V. Mukhina, G. Abramova and M. Kirmani indicate that the correlation between one's moral self with the ideal self and others' self plays an important role in the development of moral self-consciousness of children aged between 5 and 7 (Мухина, 1980; Абрамова, 2001; Kirmani, 2015). Pre-schoolers explore social environment gradually developed through their striving for live, emotional support and recognition. Realizing these needs, the child starts to appreciate moral norms (Абрамова, 2001).

Self-consciousness starts to develop dramatically at primary school age. The main factors in the development of moral consciousness and self-consciousness of primary school pupils are the sensitivity of their psyche to moral education, an uncompromising attitude to moral requirements for others and the perception of the teacher as a reference person (Гудима, 2005).

According to some scholars (Бех, 2012; Булах, 2016; Можаровська, 2016; Мухіна, 1980; Павелків, 2005; Реан, 2003), adolescence cultivates the development of moral selfconsciousness since it helps to expand moral knowledge, improve moral reflection, selfreflection, moral self-regulation and increase awareness of ethical norms of behaviour. An adolescent correlates his or her moral actions with those of his or her peers, parents, adults. At 
the same time, this period is critical for laying the foundations for moral behaviour for the future since it can result either in the positive or negative development of moral consciousness. Senior adolescents are no longer afraid of being punished and being preached. Now they actively correlate what they have heard with what they have experienced.

$\mathrm{K}$. Aquino and A. Reed assume that some adolescents may have a life experience that impedes their moral development. They may have witnessed how adults were making immoral decisions neglecting the rights and well-being of others, thus developing adolescents' beliefs and values which are not accepted in society. Without a moral compass, such adolescents can never reach their full potential and may have difficulty developing meaningful and rewarding relationships with others (Aquino \& Reed, 2002).

The paper aims to theoretically identify psychological characteristics and mechanisms for developing moral self-consciousness during preschool, primary school and adolescence years. The main tasks are a psychological analysis and, based on it, the generalization of characteristics of developing moral self-consciousness in childhood and adolescence.

\section{Research methods}

Research methods include analysis, synthesis and generalization of scientific works which disclose psychological characteristics of developing moral self-consciousness, as well as identify the mechanisms for developing them in childhood and adolescence.

\section{Results and discussion}

The development of moral consciousness consists of certain stages. L. Kolberg relies on Piaget's idea that the evolution of child's moral development runs parallel with his or her mental development and identifies three levels in the child's moral consciousness: 1) a pre-moral (preconventional) level (age of 4-10) - the child follows his or her selfish motives, and his or her actions are determined by external circumstances, without taking into account other people's views; 2) a conventional level (age of 10-13) - it is characterized by the focus on external norms and requirements and, therefore, the child's judgments are based on obtaining approval from other people, as well as respect for the established order and requirements of society; 3) a postconventional level (autonomous morality) (from age of 13) - the child is aware of relativity and conditionality of moral rules and needs to justify them logically and consider them useful. At this stage, external morality becomes internal, and relativism is replaced with the recognition of a higher law that is in the interests of the majority. Judging by one's criteria, one judges one's and others' behaviour (Kolberg, 1963).

Summarizing works of philosophers, ethicians, educators and psychologists, I. Bekh, V. Kyrychok, K. Chorna and I. Shkilna identify the following functions of moral selfconsciousness: self-acceptance, self-cognition, self-praise, moral self-esteem; moral assessment of others (juniors, peers, seniors, group, society, civilization); moral reflection (ability to comprehend one's qualities, motives, consequences of one's actions, as well as actions for oneself and others; ability to reconcile goals of one's behaviour with means of their achievement); moral self-control and behavioural correction; moral self-development (acquiring new values, developing ability to choose freely and responsibly, achieve freedom, expand one's moral experience of values-based attitude towards oneself and others) (Бех, Киричок, Чорна \& Шкільна, 2016). 
Moral self-consciousness is not only an understanding of certain problems and life circumstances in terms of moral values recognized by a particular person. It is also one's selfesteem and attempts to understand the fairness and validity of moral principles underpinning it.

Moral self-consciousness consists of three components: an affective (emotional) component, a cognitive component and behavioural (regulative) components. The main content characteristics of the cognitive component of moral self-consciousness are moral knowledge, beliefs and reflection. The emotional component of moral self-consciousness implies moral values and feelings. The behavioural component is moral self-regulation. These components develop unevenly at a certain age stage (Котлова, 2020).

D. Narvaez and A. Beaumaris significantly contribute to modern studies on moral consciousness and self-consciousness of pre-schoolers (Narvaez, 2005; Beaumaris, 2010). Having analyzed their findings, L. Lokhvyska notes that the results of their experiments indicate that moral abilities are somehow innate (Лохвицька, 2016). According to D. Narvaez, people have moral feelings which develop naturally but require a normal environment which can contribute to their "fostering" (Narvaez, 2005). The prevailing component in the development of early forms of children's moral self-consciousness are emotions, which he considers as "important blocks for developing moral thought and action". He believes that "we need both moods and reasons" to choose morally (Лохвицька, 2016: 53).

At older preschool age, self-esteem becomes one of the leading motives which stimulates child activity. At the same time, the real and the ideal self, as well as a sound grasp of highly values qualities in society, are not yet clearly differentiated in his or her moral selfconsciousness. It leads to a major contradiction in the development of the child's moral selfconsciousness, namely, between his or her idealization of himself or herself and experiences associated with how he or she is perceived by others. It further stimulates the development of reflection (Котлова, 2018).

Older pre-schoolers start to perceive moral assessment of actions and acts as their assessment rather than external demands, as pointed out by P. Yakobson (Якобсон, 1998). Learning moral requirements implies developing their structure in the child's mind. Such a structure consists of three elements: understanding of a moral meaning of actions, their assessment and an emotional attitude towards them. The whole development of the child's personality is based on the development of subordination of motives and self-consciousness. Given the development of components of moral self-consciousness (cognitive, emotional, behavioural), A. Lazarieva states that a high development level of the cognitive component prevails among pre-schoolers, along with underdeveloped emotional and behavioural ones (Лазарева, 2015).

Thus, moral self-consciousness only starts to develop at preschool age. Consequently, the changing social situation of pre-schoolers' development, the emergence of new concepts at older preschool age and the changes in the main activities contribute to the active development of moral self-consciousness at primary school age.

Given that reflection is one of the new concepts at primary school age, certain researchers (Гудима, 2005; Киричок, 2014; Павелків, 2005) believe that this age is sensitive to the development of moral consciousness and self-consciousness.

R. Pavelkiv has significantly contributed to studies on the moral consciousness and selfconsciousness at primary school age. He identifies the main characteristics of the functioning of 
moral self-consciousness at such age: 1) a high level of children's readiness to decode real and verbally presented situations in the logic of the interpersonal process along with the identification of motivational reasons behind the participants' behaviour and their consideration when assessing the normality of a certain action; 2) the connection between two moral constructs of an individual consciousness, which manifests itself in children's involuntary change of focus when performing tasks, namely from analyzing other's behaviour to analyzing personal manifestations, declaring one's positions, intentions; 3) one of the new concepts of primary school children in the field of moral consciousness and self-consciousness is the emergence of first personal moral positions, which are manifested in the desire to actively defend moral principles while there is no personal interest; making critical judgments against adults when they do not comply with moral requirements; 4) moral consciousness and self-consciousness at this age begin to function as a cohesive construct in which cognitive and axiological structures are complemented by emotional elements (Павелків, 2005).

O. Hudyma determines the following factors in the development of moral consciousness and self-consciousness at primary school age: 1) realizing and understanding moral standards and ethical values inherent in society (micro-group, group, society); 2) assessing moral actions of one's environment, literary characters, movie characters; 3) assessing one's moral actions; 4) creating such situations when pupils could feel themselves content with moral actions performed by them in the past; 5) motives of pupils' behaviour; 6) the teacher-pupil interaction related to the encouragement towards positive actions; 7) volitional capacities of pupils (Гудима, 2005).

M. Kyrychok, who deals with the issues of cultivating moral consciousness and selfconsciousness in primary school pupils, states that this process should gradually familiarize pupils with ethical categories, including moral self-consciousness, encourage pupils to understand their self-concerning the surrounding reality and others, nurture a values-based attitude towards oneself and others and develop their ability to perform noble and worthy deeds. At this age, both cognitive and emotional components of moral self-consciousness improve and become rather powerful. Indeed, at primary school age, the child reaches his or her "limit" of moral development as a whole; he or she gains certain moral experience and develops certain personality traits and habits (Киричок, 2014).

Therefore, the active involvement of primary school children in social life, as well as the emergence of new to improve during the adolescence. Adolescents' need to take a position consistent with his or her self-image may affect his or her behaviour and change their attitude towards seniors. At this age, one can observe a social reorientation of personality, which manifests itself in the emergence of "the adulthood complex". A new type of social contacts that affect the moral sphere of relationships begins to be regulated by a more complex set of personal qualities. In addition to volitional capacities, these include all kinds of moral qualities and assessments. The transition to a new level of social development requires a higher level of selfconsciousness, identification and development of those qualities that help in interpersonal interaction (Коломієць, 2016). Senior adolescents are more sensitive to moral acts of adults, especially to their kindness and justice towards them (Реан, 2003).

A. Khvostov notes that the moral consciousness of adolescents has a rather complex structure. He emphasizes moral values, principles, concepts of immorality, debt and justice, as well as views on moral qualities of individuals. The scholar believes that these components 
determine the resolution of moral conflicts, attitudes towards norms of behaviour, including politeness and tact (Хвостов, 2000).

I. Bulakh has also studied the issues of developing moral self-consciousness in adolescents and, subsequently, designed a psychological model for developing moral selfconsciousness in adolescents as the basis of their personal growth. She states that psychological mechanisms for developing moral consciousness at this age are moral self-reflection and selfregulation. The genesis of various forms of moral consciousness, such as feelings of shame, guilt, conscience, honour, dignity, responsibility, is of paramount importance to this study. On the one hand, they are deep subjective entities of adolescents. On the other hand, they are used to objectify the normative "self" of adolescents, as well as values-based attitudes to the surrounding world and oneself (Булах, 2016).

Another important factor in the development of moral self-reflection is the emotional and sensual sphere of adolescents. In this regard, I. Bekh, I. Bulakh and L. Zhuravleva assume that the leading activity of this age, namely, personal communication with peers, leads to the intensive growth of social and axiological motives and experiences. Indeed, adolescents become more empathetic and especially vulnerable to injustice and dishonesty (Бех, 2012; Булах, 2016; Журавльова, 2014). However, as pointed out by Yu. Aleksieieva, those adolescents who have well-developed moral feelings but lack moral habits, can experience certain moral conflicts with themselves due to different moral feelings (Алексєєва, 2006).

A. Zymianskyi identifies psycho-pedagogical conditions for developing adolescents' moral self-consciousness: organizing adolescents' moral activities (communication, learning, socially useful activities, games); interacting with adolescents based on moral principles; ensuring adolescents' understanding of ideal morality (moral ideals), moral principles and norms; educating parents and educators about the tasks and means of developing moral selfconsciousness in adolescents (Зимянський, 2009). Thus, the period of transition from childhood to adolescence is important and contributes to the development of one's moral identity. It is during adolescence that "the solid foundation" of the adult's moral behaviour is laid, and this must be taken into account during the educational process.

\section{Conclusions}

The summarization of the above-mentioned material allows one to draw the following conclusions: a theoretical analysis of scientific works on the problem under study proves that moral self-consciousness has its features and mechanisms of development at each age stage.

This research does not disclose all aspects of the raised multi-faceted problem of psychological characteristics of moral self-consciousness during childhood and adolescence. Further research should study the structure of moral self-consciousness of pre-schoolers, primary school pupils and adolescents.

\section{Literature}

1. Абрамова, Г.С. (2001). Возрастная психология. Москва : Академический проект.

2. Алексєєва, Ю.А. (2006). Становлення моральної самосвідомості підлітків у процесі психологічного консультування. (Дис. канд. психол. наук). Київ.

3. Бех, І.Д. (2012). Особистість у просторі духовного розвитку. Київ : Академвидав.

4. Бех, І.Д, Чорна, К.І., Журба, К.О., Киричок, В.А., Шкільна, І.М. \& Коновець, С.В. (2016). Виховання моральної самосвідомості зростаючої особистості в позакласній діяльності загальноосвітніх навчальних закладів. Харків : «Друкарня Мадрид».

5. Бехтерев, В.М. (1994). Коллективная рефлексология. Москва : Наука. 
6. Булах, І.С. (2016). Психологія особистісного зростання підлітків: реалї та перспективи. Вінниця : ТОВ «Нілан-ЛТД».

7. Выготский, Л.С. (2005). Психология развития человека. Москва : Эксмо.

8. Гудима, О.В. (2005). Психолого-педагогічні детермінанти моральних вчинків учнів 2-3 класів. Науковий часопис НПУ імені М.П. Драгоманова, 3(27), 133-139.

9. Журавльова, Л.П. (2014). Емпатія та особистісне зростання в акмеогенезі. Наука $i$ освіта, 5, 134-141.

10. Зимянський, А.Р. (2009). Генезис форм прояву моральної самосвідомості підлітка. Проблеми загальної та педагогічної психології, 12(5), 129-135.

11. Киричок, В. (2014). Теоретичні основи виховання моральної самосвідомості молодших школярів. Теоретико-методичні проблеми виховання дітей та учнівської молодi, 8(1), 316-324. Режим доступу: http://nbuv.gov.ua/UJRN/Tmpvd_2014 18\%281\%29 37

12. Коломієць, Т.В. (2016). Розвиток емпатійної міжособистісної взаємодії в юнацькому віці. Наука і освіта, 9, 77-84. https://doi.org/10.24195/2414-4665-2016-9-15

13. Котлова, Л.О. (2018). Теоретико-методологічні засади дослідження чесності в дитячому віці. Scientific Researches. International periodics cientific journal, 3,20-29.

14. Котлова, Л.О. (2020). Структура моральної самосвідомості особистості. Науковий часопис НПУ імені М.П. Драгоманова, 9(54), 49-56. https://doi.org/10.31392/NPUnc.series $12.2020 .9(54) .08$

15. Лазарєва, О.П. (2015). Психологічні особливості розвитку моральної свідомості дітей дошкільного віку. Актуальні проблеми соиіології, психологї, педагогіки, 2, 46-55. Режим доступу: http://apspp.soc.univ.kiev.ua/index.php/home/article/view

16. Лохвицька, Л.В. (2016). Еволюція теорії морального розвитку особистості в наукових підходах зарубіжних психологів. Науковий вісник Херсонського державного університету, 3, 50-54. Режим доступу: https://pj.journal.kspu.edu/index.php/ $\mathrm{pj} /$ article/view/771/726

17. Можаровська, Т.В. (2016). Структурно-динамічна модель розвитку екологічної свідомості. Наука і освіта, 5, 124-130. https://doi.org/10.24195/2414-4665-2016-5-19

18. Мухина, В.С. (1980). К проблеме социального развития ребенка. Психологический журнал 5, 43-53.

19. Овчарова, Р.В. (2015). Нравственное самосознание и внутренняя позиция личности подростка в состоянии социально-педагогической запущенности. Фундаментальные исследования, 2, 2970-2974. Режим доступу: https://www.fundamentalresearch.ru/ru/article/view?id=37598

20. Павелків, Р.В. (2005). Розвиток моральної свідомості та самосвідомості в молодшому шкільному віці. (Дис. д-ра психол. наук). Рівне.

21. Прихожан, А.М. (1990). Подросток в учебнике и жизни. Москва : Знание.

22. Реан, А.А. (2003). Психология подростка. Санкт-Петербург : Прайм - ЕВРОЗНАК.

23. Рубинштейн, С.Л. (2006). Основы общей психологии. Санкт-Петербург : Питер.

24. Хвостов, А.А. (2000). Онтогенез морального сознания: от подростков до студенчиской молодежи. Развитие личности, 3, 75-100.

25. Шкільна, I.M. (2014). Виховання моральної самосвідомості старших підлітків як наукова проблема. Теоретико-методичні проблеми виховання дітей та учнівської молодi, 18(2), 413-421. Режим доступу: http://nbuv.gov.ua/UJRN/Tmpvd $2014 \quad 18 \% 282 \% 29 \quad 49$

26. Якобсон, П.М. (1998). Психология чувств и мотивации. Воронеж : МОДЭК ; Москва : Институт практической психологии.

27. Althof, W., \& Berkowitz, M. (2006). Moral education and character education: Their relationship and roles in citizenship education. Journal of Moral Education, 35(Dec), 495518. https://doi.org/10.1080/03057240601012204

28. Aquino, K., Reed, A. (2002). The self-importance of moral identity. Journal of Personality and Social Psychology, 83, 1423-1440. https://doi.org/doi/10.1037/0022-3514.83.6.1423

29. Bandura, A. (2018). A commentary on moral disengagement: the rhetoric and the reality. The American Journal of Psychology, 131(2), 246-251. doi:10.5406/amerjpsyc.131.2.0246

30. Beaumaris, A.R. (2010). Moral Judgment to Moral Action: Implications for Education. (Thesis of the Doctorate of Philosophy). Australia. Retrieved from https://www.academia.edu/11761859/From Moral Judgement to Moral Action

31. Kirmani, M. (2015). Developing moral behaviors in children and adolescents: Psychoquranic perspective. Indian Journal of Positive Psychology, 6(12), 207-210.

32. Kolberg, L. (1963). The development of children's orientations toward a moral order. Vita Humana, 6, 11-35. 
33. Krettenauer, T. (2020). Moral identity as a goal of moral action: A Self-Determination Theory perspective. Journal of Moral Education, Jan.

https://doi.org/10.1080/03057240.2019.1698414

34. Narvaez, D. (2005). The Neo-Kohlbergian Tradition and Beyond: Schemas, Expertise, and Character. In G. Carlo \& C.P. Edwards (Eds.), Vol. 51 of the Nebraska Symposium on motivation. Moral motivation through the life span. (pp. 119-163). University of Nebraska Press. Retrieved from https://www.researchgate.net/publication/7433452

35. Ramos, A., Griffin, A., Neiderhiser, J., \& Reiss, D. (2019). Did I inherit my moral compass? Examining socialization and evocative mechanisms for virtuous character development. Behavior Genetics, 49(2), 175-186. https://doi.org/10.1007/s10519-018-09945-4

36. Walker, L.J. (2019). The character of character: The 2019 Kohlberg Memorial Lecture. Journal of Moral Education, 48(3), 275-279.

https://doi.org/10.1080/03057240.2019.1698415

\section{References}

1. Abramova, G.S. (2001). Vozrastnaja psihologija [Developmental psychology]. Moskva : Academic Project [in Russian].

2. Aleksieieva, Ya.A. (2006). Stanovlennia moralnoi samosvidomosti pidlitkiv u protsesi psykholohichnoho konsultuvannia [Developing moral self-consciousness in adolescents during psychological counselling]. Candidate's thesis. Kyiv [in Ukrainian].

3. Bekh, I.D. (2012). Osobystist u prostori dukhovnoho rozvytku [Personality in the realm of spiritual development]. Kyiv : Akademvydav [in Ukrainian].

4. Bekh, I.D., Chorna, K.I., Zhurba, K.O., Kyrychok, V.A., Shkilna, I.M. \& Konovets, S.V. (2016). Vykhovannia moralnoi samosvidomosti zrostaiuchoi osobystosti $v$ pozaklasnii diialnosti zahalnoosvitnikh navchalnykh zakladiv [Developing moral self-consciousness in a growing personality through extracurricular activities in secondary schools]. Kharkiv : Drukarnia Madryd [in Ukrainian].

5. Bekhterev, V.M. (1994). Kollektivnaja refleksologija [Collective reflexology]. Moskva: Nauka [in Russian].

6. Bulakh, I.S. (2016). Psykholohiia osobystisnoho zrostannia pidlitkiv: realii ta perspektyvy [Psychology of adolescents' personal growth: realities and prospects]. Vinnytsia : Nilan LTD [in Ukrainian].

7. Vygotsky, L.S. (2005). Psihologija razvitija cheloveka [The psychology of human development]. Moskva : Jeksmo [in Russian].

8. Hudyma, O.V. (2005). Psykholoho-pedahohichni determinanty moralnykh vchynkiv uchniv 2-3 klasiv [Psychological and pedagogical determinants of moral actions of second- and third-grades]. Naukovyi chasopys NPU imeni M.P. Drahomanova - Scientific Journal of Drahomanov National Pedagogical University, 3 (27), 133-139 [in Ukrainian].

9. Zhuravleva, L.P. (2014). Empatiia ta osobystisne zrostannia v akmeohenezi [Empathy and personal growth in acmeogenesis]. Nauka $i$ osvita - Science and Education. 5, 134-141 [in Ukrainian].

10. Zymianskyi, A.R. (2009). Henezys form proiavu moralnoi samosvidomosti pidlitka [The origins of manifestation forms of adolescents' moral self-consciousness]. Problemy zahalnoi ta pedahohichnoi psykholohii - Problems of General and Educational Psychology, 12(5), 129-135 [in Ukrainian].

11. Kyrychok, V. (2014). Teoretychni osnovy vykhovannia moralnoi samosvidomosti molodshykh shkoliariv [Theoretical principles of developing moral self-consciousness in younger pupils]. Teoretyko-metodychni problemy vykhovannia ditei ta uchnivskoi molodi Theoretical and Methodological Problems of Educating Children and Pupils, 8(1), 316-24. Retrieved from http://nbuv.gov.ua/UJRN/Tmpvd_2014_18\%281\%29 37 [in Ukrainian].

12. Kolomiets, T.V. (2016). Rozvytok empatiinoi mizhosobystisnoi vzaiemodii v yunatskomu vitsi [Developing empathic interpersonal interaction during the adolescence]. Nauka $i$ osvita - Science and Education. 9, 77-84. https://doi.org/10.24195/2414-4665-2016-9-15 [in Ukrainian].

13. Kotlova, L.O. (2018). Teoretyko-metodolohichni zasady doslidzhennia chesnosti v dytiachomu vitsi [Theoretical and methodological principles of studying honesty in childhood]. Modern Scientific Researches. International Periodics Scientific Journal, 3, 2029 [in Ukrainian].

14. Kotlova, L.O. (2020). Struktura moralnoi samosvidomosti osobystosti [The structure of the individual's moral self-consciousness]. Naukovyi chasopys NPU imeni M.P. Drahomanova- 
Scientific Journal of Drahomanov National Pedagogical University, 9(54), 49-56. https://doi.org/10.31392/NPU-nc.series12.2020.9(54).08 [in Ukrainian].

15. Lazarieva, O.P. (2015). Psykholohichni osoblyvosti rozvytku moralnoi svidomosti ditei doshkilnoho viku [Psychological characteristics of developing moral consciousness in preschoolers]. Aktualni problemy sotsiolohii, psykholohii, pedahohiky - Relevant Problems of Sociology, Psychology, Pedagogy, 2, 46-55. Retrieved from http://apspp.soc.univ.kiev.ua/index.php/home/article/view [in Ukrainian].

16. Lokhvytska, L.V. (2016). Evoliutsiia teorii moralnoho rozvytku osobystosti $v$ naukovykh pidkhodakh zarubizhnykh psykholohiv [Evolution of the theory of the individual's moral development in scientific approaches of international psychologists]. Naukovyi visnyk Khersonskoho derzhavnoho universytetu - Scientific Journal of Kherson State University, 3, 50-54. Retrieved from https://pj.journal.kspu.edu/index.php/pj/article/view/771/726 [in Ukrainian].

17. Mozharovska, T.V. (2016). Ctrukturno-dynamichna model rozvytku ekolohichnoi svidomosti [The structural-and-dynamic model of developing environmental consciousness]. Nauka $i$ osvita - Science and Education, 5, 124-130. https://doi.org/10.24195/2414-4665-2016-5-19 [in Ukrainian].

18. Mukhina, V.S. (1980). K probleme social'nogo razvitija rebenka [On the problem of the child's social development]. Psihologicheskij zhurnal - Psychological Journal, 5, 43-53 [in Russian].

19. Ovcharova, R.V. (2015). Nravstvennoe samosoznanie i vnutrennjaja pozicija lichnosti podrostka v sostojanii social'no-pedagogicheskoj zapushhennosti [Moral self-consciousness and internal position of the adolescent's personality in a state of socio-pedagogical neglect]. Fundamental'nye issledovanija - Fundamental Research, 2, 2970-2974. Retrieved from https://www.fundamental-research.ru/ru/article/view?id=37598 [in Russian].

20. Pavelkiv, R.V. (2005). Rozvytok moralnoi svidomosti ta samosvidomosti v molodshomu shkilnomu vitsi [Developing moral consciousness and self-consciousness at primary school age]. Doctor's thesis. Rivne [in Ukrainian].

21. Prikhozhan, A.M. (1990). Podrostokv uchebnike i zhizni [Adolescents in textbooks and life]. Moskva : Znanye [in Russian].

22. Rean, A.A. (2003). Psihologija podrostka [The psychology of adolescents]. SanktPeterburg : Prajm-EVROZNAK [in Russian].

23. Rubinstein, S.L. (2006). Osnovy obshhej psihologii [The fundamentals of general psychology]. Sankt-Peterburg : Piter [in Russian].

24. Khvostov, A.A. (2000). Ontogenez moral'nogo soznanija: ot podrostkov do studenchiskoj molodezhi [The ontogenesis of moral consciousness: from adolescents to college students]. Razvitie lichnosti - Personality Development, 3, 75-100 [in Russian].

25. Shkilna, I.M. (2014). Vykhovannia moralnoi samosvidomosti starshykh pidlitkiv yak naukova problema [Developing moral consciousness in senior adolescents as a scientific problem]. Teoretyko-metodychni problemy vykhovannia ditei ta uchnivskoi molodi Theoretical and Methodological Problems of Educating Children and Pupils, 18(2), 413421. Retrieved from http://nbuv.gov.ua/UJRN/Tmpvd $2014 \quad 18 \% 282 \% 29 \quad 49$ [in
[in Ukrainian].

26. Yakobson, P.M. (1998). Psihologija chuvstv $i$ motivacii [Psychology of feelings and motivation]. Voronezh : MODEK; Moskva : Institut prakticheskoj psihologii [in Russian].

27. Althof, W., \& Berkowitz, M. (2006). Moral education and character education: their relationship and roles in citizenship education. Journal of Moral Education, 35, 495-518. https://doi.org/10.1080/03057240601012204

28. Aquino, K., \& Reed, A. (2002). The self-importance of moral identity. Journal of Personality and Social Psychology, 83, 1423-1440. https://doi.org/doi/10.1037/00223514.83.6.1423

29. Bandura, A. (2018). A commentary on moral disengagement: the rhetoric and the reality. The American Journal of Psychology, 131(2), 246-251. doi:10.5406/ameripsyc.131.2.0246

30. Beaumaris, A.R. (2010). Moral judgment to moral action: implications for education. Doctor's thesis. Australia. Retrieved from https://www.academia.edu/11761859/ From Moral Judgement to Moral Action

31. Kirmani, M. (2015). Developing moral behaviors in children and adolescents: Psychoquranic perspective. Indian Journal of Positive Psychology, 6(12), 207-210.

32. Kolberg, L. (1963). The development of children's orientations toward a moral order. Vita Humana, 6, 11-35. 
33. Krettenauer, T. (2020). Moral identity as a goal of moral action: a self-determination theory perspective. Journal of Moral Education, 1. https://doi.org/10.1080/03057240.2019.1698414

34. Narvaez, D. (2005). The neo-Kohlbergian tradition and beyond: schemas, expertise, and character. In G. Carlo \& C.P. Edwards (Eds.), The Nebraska Symposium on Motivation. Moral Motivation through the Life Span (Vol. 51, p. 119-163). Lincoln, NE; London: University of Nebraska Press.

Retrieved from https://www.researchgate.net/publication/7433452

35. Ramos, A., Griffin, A., Neiderhiser, J., \& Reiss, D. (2019). Did I inherit my moral compass? Examining socialization and evocative mechanisms for virtuous character development. Behavior Genetics, 49(2), 175-186. https://doi.org/10.1007/s10519-018-09945-4

36. Walker, L.J. (2019). The character of character: The 2019 Kohlberg memorial lecture. Journal of Moral Education, 48(3), 275-279.

https://doi.org/10.1080/03057240.2019.1698415

\section{ПСИХОЛОГІЧНА ХАРАКТЕРИСТИКА МОРАЛЬНОЇ САМОСВІДОМОСТІ В ПЕРІОДИ ДИТИНСТВА І ДОРОСЛІШАННЯ Людмила Котлова \\ кандидат психологічних наук, доцент, доцент кафедри психології розвитку та консультування \\ Житомирський державний університет імені Івана Франка \\ 10008 , Україна, м. Житомир, вул. Велика Бердичівська, 40 \\ kotlova.1o@i.ua, https://orcid.org/0000-0003-2994-6724}

\section{Анотація}

Статтю присвячено теоретичному аналізу психологічних особливостей моральної самосвідомості в дошкільному, молодшому шкільному і підлітковому віці. Моральна самосвідомість розглядається як специфічна форма моральної свідомості, усвідомлення себе, своїх моральних цінностей, ставлень, якостей, потенційних можливостей, вчинків, їх мотивів і наслідків, регулювання власної поведінки та моральне самовдосконалення. Мета статті - теоретичне виокремлення психологічних особливостей і механізмів розвитку моральної самосвідомості в дошкільному, молодшому шкільному та підлітковому віці. Основними завданнями стали психологічний аналіз та узагальнення особливостей розвитку моральної самосвідомості в дитячому і підлітковому віці. Методи аналізу, синтезу й узагальнення застосовані щодо наукових праць, у яких розглянуто психологічні особливості становлення моральної самосвідомості особистості, виокремлено механізми іiі розвитку в дитячому віці та в період дорослішання. Встановлено, що у старшому дошкільному віці самооцінка стає одним із провідних мотивів, що стимулює до активності дитини, але в їі моральній самосвідомості ще недостатньо чітко диференційовані реальний та ідеальний образ «Я», звідси і впевненість у володінні високо-цінними в суспільстві особистісними якостями, неузгодженість у розвитку моральної самосвідомості - між ідеалізацією самої себе та переживаннями, пов’язаними 3 тим, як її оцінюють інші. Значного розвитку досягає самосвідомість у молодшому шкільному віці, у зв'язку зі вступом дитини до школи. Основними чинниками розвитку моральної самосвідомості молодших школярів $є$ сенситивність психіки дітей цього віку до морального виховання, безкомпромісність у моральних вимогах до інших, сприймання вчителя як референтної особи. Самосвідомість $\epsilon$ важливим чинником розвитку в підлітковому віці, коли бурхливо розвивається рефлексія, формується Я-образ, усвідомлюються мотиви власної діяльності, відбувається інтимізація внутрішнього життя. Отже, період переходу від дитинства до дорослості $є$ важливим і сприятливим для розвитку моральної самосвідомості особистості. В підлітковому віці закладається «міцний фундамент» моральної поведінки дорослої людини, і це необхідно враховувати під час освітньо-виховного процесу.

Ключові слова: моральна самосвідомість, моральна поведінка, почуття, рефлексія, свідомість, самосвідомість. 